\title{
Levels of $E, A, M, G$ immunoglobulins in children with newly diagnosed tuberculosis at the beginning of antimycobacterial therapy
}

\author{
0. M. Raznatovska, Yu. V. Mironchuk, O. S. Lytvynenko
}

Zaporizhzhia State Medical University, Ukraine

Key words: immunoglobulins, children, tuberculosis.

\section{Zaporozhye} medical journa 2018; 20 (1), 86-90

DOI:

10.14739/2310-1210

2018.1.122003

E-mail:

raxnatovskaya@

gmail.com

Tuberculosis in children is a chronic inflammatory process in which immunological mechanisms occupy one of the leading positions in pathogenesis. Therefore, the immune status indicators study among children makes it possible to determine the disease activity, predict its course for the purpose of revealed violations early correction and determine the effectiveness of the treatment. One of the immunological indicators of tuberculosis is immunoglobulins level.

The aim of the work - to investigate IgE, A, M, G levels in children's blood serum with newly diagnosed tuberculosis at the beginning of antimycobacterial therapy for further development of rationally directed immunocorrective therapy.

Materials and methods. The study of $\lg E, A, M, G$ levels in blood serum was performed in 28 children with newly diagnosed tuberculosis aged 1 to 16 years (average age was $9.2 \pm 1.1$ years old). The levels of $\lg \mathrm{E}, \lg \mathrm{A}, \lg \mathrm{M}$ and $\lg \mathrm{G}$ in the blood serum were studied using the method of solid phase enzyme-linked immunosorbent assay on the equipment of the Sirio $S$ immunoenzyme reader with the use of reagent kits "Granum" LLC (Kharkiv, Ukraine). The results of the study were processed by modern methods of analysis on a personal computer using statistical software package Statistica ${ }^{\circledR}$ for Windows 6.0 (StatSoft Inc., AXXR712 D833214FAN5).

Results. Children with newly diagnosed tuberculosis at the beginning of the intensive phase of antimycobacterial therapy had a significant increase in IgE and A levels in 2.1 and 1.2 times respectively. With an increase in the prevalence of a specific process and the appearance of destruction, there is a significant increase in the lgG level in 1.2 times. Direct correlations between IgE and IgA, IgA and IgM, IgM and IgG in the disseminated process, and IgA, IgM levels in the local process have been found. A reliable correlation between the decrease in the BCG post-vaccination sign size and the increase in lgE content has been revealed, that may be a prognostic factor in the post-vaccination immunity evaluation. Cellular component of immune system activation is determined in the children, as evidenced by a significant increase in albumins level in 1.5 times against the background of the specific inflammatory process low activity ( $\alpha_{1}$ - and $\alpha_{2}$-globulins levels were within the age norm). There is a significant worsening of dysproteinemia (a decrease in albumin levels by $9 \%$ and an increase in $\beta$ - and $\gamma$-globulins levels in 1.3 times) and specific inflammatory process activity (an increase in $\alpha_{1}$-globulin level in 1.3 times) with the increase in the specific process prevalence and destruction development. It has been established that the decrease in the albumin level is associated with growth in the $\operatorname{lgE}, A$ and $G$ levels; growth in the $\beta$-globulin level is associated with growth in the $\lg A$ and $G$ levels, and with $\lg E, M$, and $G$ - in $\gamma$-globulins. It has been found that $\lg A, M$ and $G$, and the protein fractions parameters albumins, $\beta$ - and $\gamma$-globulins are significant and highly informative for the immune changes diagnosis in children with newly diagnosed tuberculosis.

Conclusions. In children with newly diagnosed pulmonary tuberculosis at the beginning of an intensive phase of antimycobacterial therapy with increase in the specific process prevalence and destruction development, significant changes in the levels of immunoglobulins and protein fractions are observed. Data resulting from the study suggest that the humoral component of immune system is also activated on the background of the cellular component of immune system activation with patient's state aggravation, which is an unfavorable prognosis for patients' recovery.

Ключові слова: імуноглобуліни, Аіти, туберкульоз.

\section{Запорізький} медичний журнал. - 2018. -

T. 20, № 1(106). -

C. 86-90

\section{Рівні імуноглобулінів Е, А, M, G у дітей, які хворі на вперше діагностований туберкульоз, на початку антимікобактеріальної терапії}

\section{О. М. Разнатовська, Ю. В. Мирончук, О. С. Аитвиненко}

Туберкульоз у дітей - це хронічний запальний процес, у якому імунологічні механізми посідають одне з провідних місць у патогенезі. Отже, вивчення показників імунного статусу в дітей дає можливість визначити активність захворювання, спрогнозувати його перебіг для ранньої корекції виявлених порушень, визначити ефективність лікування. Одними з імунологічних показників при туберкульозі є імуноглобуліни.

Мета роботи - дослідити рівні IgE, A, M, G у сироватці крові дітей, які хворі на вперше діагностований туберкульоз, на початку антимікобактеріальної терапії для дальшої розробки раціонально спрямованої імунокоригувальної терапії.

Матеріали та методи. Вивчили рівні показників $\mathrm{IgE}, \mathrm{A}, \mathrm{M}, \mathrm{G}$ у сироватці крові у 28 дітей, які хворі на вперше діагностований туберкульоз, віком від 1 до 16 років (середній вік 9,2 $\pm 1,1$ року). Рівні показників $\lg \mathrm{E}$, IgA, $\lg \mathrm{M}$ та $\lg \mathrm{g}$ у сироватці крові вивчали методом твердофразного імунофрерментного аналізу на приладі імуноферментний рідер Sirio $S$ із застосуванням наборів реактивів ТОВ НВЛ «Гранум» (м. Харків). Результати дослідження опрацьовані сучасними методами аналізу з використанням статистичного пакета ліцензійної програми Statistica ${ }^{\circledR}$ for Windows 6.0 (StatSoft Inc., № AXXR712 D833214FAN5).

Результати. У дітей, які хворі на вперше діагностований туберкульоз, на початку інтенсивної фази антимікобактеріальної терапії визначається вірогідне зростання рівнів IgE та A у 2,1 та 1,2 раза, відповідно. При наростанні поширення специфічного процесу та появі деструкцій спостерігається вірогідне зростання рівня IgG у 1,2 раза. При поширеному 
процесі встановлені прямі кореляційні зв'язки рівнів $\lg \mathrm{E}$ та $\lg \mathrm{A}$, IgA та $\lg \mathrm{M}$, $\lg \mathrm{M}$ та $\lg \mathrm{G}$, а при обмеженому - між $\lg \mathrm{A}$ та $\lg \mathrm{M}$. Встановлено вірогідний кореляційний зв'язок між зменшенням розміру післявакцинального знака БЦЖ і наростанням вмісту $\lg \mathrm{E}$, що може бути прогностичним фрактором в оцінюванні післявакцинального імунітету. У дітей визначається активація клітинної ланки імунної системи, про що свідчило вірогідне підвищення у 1,5 раза рівня альбумінів на тлі низької активності специфічного запального процесу (рівні $\alpha_{1}$ - та $\alpha_{2}$-глобулінів перебували в межах вікової норми). При цьому при наростанні поширеності специфічного процесу та появі деструкцій спостерігалось вірогідне наростання диспротеїнемії (зниження рівня альбуміну на 9 \% і зростання рівнів $\beta$ - та ү-глобулінів у 1,3 раза) та активності запального специфічного процесу (зростання рівня а $\alpha_{1}$-глобуліну в 1,3 раза). Встановили, що зниження рівня альбумінів пов'язано зі зростанням рівнів $\lg E, A$ та $\mathrm{G}$, зростання рівнів $\beta$-глобулінів - зі зростанням рівнів $\lg A$ та $\mathrm{G}$, а ү-глобулінів - $\lg \mathrm{E}, \mathrm{M}$, G. Виявили, що діагностично значущими та високоінформативними для діагностики змін імунітету $є \operatorname{lgA}, \mathrm{M} \mathrm{i} \mathrm{G}$, а серед показників білкових фракцій - альбуміни, $\beta$ - та ү-глобуліни.

Висновки. У дітей, які хворі на вперше діагностований туберкульоз легень, на початку інтенсивної фрази антимікобактеріальної терапії при наростанні поширеності специсічного процесу та появі деструкцій спостерігаються вірогідні зміни рівнів імуноглобулінів і білкових фракцій. Дані, що одержали, свідчать: на тлі активації клітинної ланки імунної системи з погіршенням стану відбувається активація гуморальної ланки, а це є несприятливий прогноз для одужання пацієнтів.

\section{Уровни иммуноглобулинов E, A, M, G у детей, больных впервые диагностированным туберкулезом, в начале антимикобактериальной терапии}

\section{Е. Н. Разнатовская, Ю. В. Мирончук, Е. С. Аитвиненко}

Туберкулез у детей - это хронический воспалительный процесс, в котором иммунологические механизмы занимают одно из ведущих мест в патогенезе. Поэтому изучение показателей иммунного статуса у детей дает возможность определить активность заболевания, спрогнозировать его течение с целью ранней коррекции выявленных нарушений, определить эффрективность проводимого лечения. Одними из иммунологических показателей при туберкулезе являются иммуноглобулины.

Цель работы - исследовать уровни $\lg E, A, M, G$ в сыворотке крови детей, больных впервые диагностированным туберкулезом, в начале антимикобактериальной терапии для дальнейшей разработки рационально направленной иммунокорригирующей терапии.

Материалы и методы. Изучение уровней показателей $\mathrm{IgE}, \mathrm{A}, \mathrm{M}, \mathrm{G}$ в сыворотке крови проведено у 28 детей, больных впервые диагностированным туберкулезом, в возрасте от 1 до 16 лет (средний возраст 9,2 \pm 1,1 года). Уровни показателей $\lg \mathrm{E}, \lg \mathrm{A}, \lg \mathrm{M}$ и $\lg \mathrm{G}$ в сыворотке крови изучали методом твердофазного иммуноферментного анализа на приборе иммуноферментный ридер Sirio S с применением наборов реактивов ООО НПЛ «Гранум» (г. Харьков, Украина). Результаты исследования обработаны современными методами анализа с использованием статистического пакета лицензионной программы Statistica ${ }^{\circledR}$ for Windows 6.0 (StatSoft Inc., № AXXR712 D833214FAN5).

Результаты. У детей, больных впервые диагностированным туберкулезом, в начале интенсивной фазы антимикобактериальной терапии определяется достоверное повышение уровней $\lg$ и и А в 2,1 и 1,2 раза соответственно. При нарастании распространенности специфического процесса и появлении деструкции наблюдается достоверный рост уровня $\operatorname{lgG}$ в 1,2 раза. При распространенном процессе установлены прямые корреляционные связи уровней $\lg \mathrm{E}$ и $\lg \mathrm{A}, \lg \mathrm{A}$ и $\lg \mathrm{M}$, IgM и IgG, а при ограниченном - между $\lg \mathrm{A}$ и $\lg$ М. Установлена достоверная корреляционная связь между уменьшением размера поствакцинального знака БЦЖ и нарастанием содержания IgE, что может быть прогностическим фактором в оценке поствакцинального иммунитета. У детей определяется активация клеточного звена иммунной системы, о чем свидетельствовало достоверное повышение в 1,5 раза уровня альбуминов на фоне низкой активности специфического воспалительного процесса (уровни $\alpha_{1}-$ и $\alpha_{2}$-глобулинов находились в пределах возрастной нормы). При этом при нарастании распространенности специфического процесса и появлении деструкции наблюдается достоверное нарастание диспротеинемии (снижение уровня альбумина на 9 \% и ростом уровней $\beta-и$ ү-глобулинов в 1,3 раза) и активности воспалительного специфического процесса (повышение уровня $\alpha_{1}$-глобулина в 1,3 раза). Установлено, что снижение уровня альбумина связано с повышением уровней $\lg \mathrm{E}, \mathrm{A}$ и $\mathrm{G}$, рост уровня $\beta$-глобулинов связан с ростом уровней IgA и G, а ү-глобулинов - IgE, M и G. Установлено, что диагностически значимыми и высокоинформативными для диагностики изменений иммунитета являются $\lg A, \mathrm{M}$ и G, а среди показателей белковых фракций - альбумины, $\beta$ - и ү-глобулины.

Выводы. У детей, больных впервые диагностированным туберкулезом легких, в начале интенсивной фазы антимикобактериальной терапии при нарастании распространенности специфического процесса и появления деструкции наблюдаются достоверные изменения уровней иммуноглобулинов и белковых фракций. Полученные данные свидетельствуют: на фоне активации клеточного звена иммунной системы с утяжелением состояния происходит активация гуморального звена, что является неблагоприятным прогнозом для выздоровления пациентов.

Tuberculosis in children is a chronic inflammatory process in which immunological mechanisms occupy one of the leading positions in pathogenesis. Therefore, the immune status indicators study among children makes it possible to determine the disease activity, predict its course for the purpose of revealed violations early correction and determine the effectiveness of the treatment $[1,2]$.
Ключевые слова: иммуноглобулины, Аети, туберкулез.

Запорожский медицинский журнал. - 2018. T. 20, № 1(106). C. $86-90$
One of the immunological parameters for tuberculosis is immunoglobulins level [3]. Immunoglobulins (Ig) are plasma proteins that are synthesized by B-lymphocytes and provide specific immunological protection of an organism, and are indicators of humoral immunity. Due to the ability of $\lg E$ to bind to membranes receptors on mast cells and basophils, the release of allergy mediators occurs. Two fractions of IgA 
are excreted in a human body: serum and secretory. Serum IgA provides local immunity, and secretory participates in providing protection of mucous membranes (respiratory, urogenital tract and digestive tract) from microorganisms, including mycobacterium tuberculosis (MBT). The decrease in IgA level indicates a lack of humoral local immunity, and in the absence of appropriate treatment it leads to the immune system depletion, which causes infectious process inhibition, etc. Increase in IgAlevel is observed in infectious diseases, both in acute and chronic exacerbation processes [4]. Under the influence of IgM the compliment system is activated in response to an acute infectious process, providing primary immunity. Serum IgG provides long-term humoral immunity to infectious agents. In chronic infectious and autoimmune diseases an increase in the serum lgG level is detected and its deficiency contributes to the weakening of a body resistance to infectious diseases.

\section{Purpose}

To investigate $\lg \mathrm{E}, \mathrm{A}, \mathrm{M}, \mathrm{G}$ levels in children's blood serum with newly diagnosed tuberculosis at the beginning of anti-

Table 1. Blood serum levels of total lgE, A, M, G among children with NDTB at the beginning of IF AMBT $(M \pm m)$

\begin{tabular}{|c|c|c|c|c|c|}
\hline \multirow[t]{2}{*}{ Groups } & \multirow{2}{*}{$\begin{array}{l}\text { Number } \\
\text { of persons }\end{array}$} & \multicolumn{4}{|c|}{ Ig blood serum levels } \\
\hline & & $\lg \mathrm{E}(\mathrm{MU} / \mathrm{ml})$ & $\lg A(g / l)$ & $\lg M(g / l)$ & $\lg G(g / l)$ \\
\hline Comparison group & 30 & $55.8 \pm 4.8$ & $1.24 \pm 0.1$ & $1.28 \pm 0.11$ & $8.21 \pm 0.64$ \\
\hline Basic group & 28 & $121.0 \pm 30.9^{*}$ & $1.59 \pm 0.1^{*}$ & $1.14 \pm 0.03$ & $8.74 \pm 0.3$ \\
\hline
\end{tabular}

*: the difference in the content of Ig certain type in comparison with the healthy children indicator $(P<0.05)$.

Table 2. IgE, A, M, G blood serum levels in children with NDTB depending on tuberculosis prevalence $(\mathrm{M} \pm \mathrm{m})$

\begin{tabular}{lllll}
\hline $\begin{array}{l}\text { Prevalence } \\
\text { of tuberculosis }\end{array}$ & \multicolumn{4}{l}{$\lg$ blood serum levels } \\
\cline { 2 - 5 } $\operatorname{lgE}(\mathrm{MU} / \mathrm{ml})$ & $\operatorname{lgA}(\mathbf{g} / \mathbf{l})$ & $\operatorname{lgM}(\mathbf{g} / \mathbf{l})$ & $\lg \mathbf{g}(\mathbf{g} /)$ \\
\hline Local $(\mathrm{n}=13)$ & $105.5 \pm 25.3$ & $1.52 \pm 0,1$ & $1.18 \pm 0.05$ & $7.77 \pm 0.2$ \\
Disseminated $(\mathrm{n}=15)$ & $134.5 \pm 53.2$ & $1.64 \pm 0,1$ & $1.10 \pm 0.04$ & $9.59 \pm 0.4^{*}$ \\
\hline
\end{tabular}

*: the difference in the content of $\lg$ certain type in the processes $(P<0.05)$.

Table 3. Concentration of blood serum protein fractions in children with NDTB at the beginning of IF AMBT $(\mathrm{M} \pm \mathrm{m})$

\begin{tabular}{lll}
\hline Indicator, \% & Comparison group $(\mathbf{n}=\mathbf{3 0})$ & Main group $(\mathbf{n}=\mathbf{2 8})$ \\
\hline Albumens & $40.93 \pm 0.7$ & $61.91 \pm 1.7^{*}$ \\
$\alpha_{1}$-globulins & $3.68 \pm 0.2$ & $3.79 \pm 0.3$ \\
$\alpha_{2}$-globulins & $8.05 \pm 0.1$ & $8.43 \pm 1.3$ \\
$\beta$-globulins & $7.36 \pm 0.2$ & $11.43 \pm 0.7^{\star}$ \\
y-globulins & $11.42 \pm 0.7$ & $15.64 \pm 1.0^{*}$ \\
\hline
\end{tabular}

*: the indicator difference in comparison with the group indicators of healthy children $(P<0.05)$.

Table 4. Blood serum concentration of protein fractions in children with NDTB depending on tuberculosis prevalence of $(\mathrm{M} \pm \mathrm{m})$

\begin{tabular}{lll}
\hline Indicators, \% & Comparison group $(\mathbf{n}=13)$ & Main group $(\mathbf{n}=15)$ \\
\hline Albumens & $66.7 \pm 1.4$ & $57.8 \pm 2.4^{*}$ \\
$\alpha_{1}$-globulins & $3.2 \pm 0.3$ & $4.3 \pm 0.4^{*}$ \\
$\alpha_{2}$-globulins & $6.8 \pm 0.5$ & $9.8 \pm 2.4$ \\
$\beta$-globulins & $9.7 \pm 0.6$ & $12.9 \pm 1.2^{*}$ \\
y-globulins & $13.5 \pm 1.3$ & $17.5 \pm 1.2^{*}$ \\
\hline
\end{tabular}

*: the difference between the groups $(P<0.05)$. mycobacterial therapy for further development of rationally directed immunocorrective therapy.

\section{Materials and methods}

The study of $\lg E, A, M, G$ levels in blood serum was performed in 28 children with NDTB aged 1 to 16 years (average age was $9.2 \pm 1.1$ years old) who were on inpatient treatment in a children's unit of the clinical base of Phthisiology and Pulmonology Department of Zaporizhzhia State Medical University at Communal Institution "Zaporizhzhia Regional Antituberculous Clinical Dispensary" and constituted the main group. There were $16(57.1 \%)$ girls and 12 $(42.9 \%)$ boys. The comparison group included 30 healthy children aged 1 to 16 (average age was $8.9 \pm 1.0$ years old). The comparison group were comparable to age and gender.

The levels of $\lg E$, $\lg A$, $\lg M$ and $\lg G$ in the blood serum were studied using the method of solid phase enzyme-linked immunosorbent assay on the equipment of the Sirio S immuno-enzyme reader with the use of reagent kits "Granum" LLC (Kharkiv, Ukraine). Units of measurement: IgE (MU/ml), $\operatorname{lgA}, M, G(g / l)$. The analysis of blood serum protein fractions parameters was carried out using rheum sampling electrophoresis method with distribution on acetate-cellulose film on the fraction. The levels of albumins and globulins $\left(\alpha_{1}\right.$, $\left.\alpha_{2}, \beta, \gamma\right),(\%)$ were determined [5].

All indicators were evaluated at the beginning of the intensive phase (IF) of antimycobacterial therapy (AMBT). Parents of all sick children signed a patient's written informed consent to participate in the study.

The diagnostic significance of indicators assessment was carried out using the diagnostic utility coefficient (DUC) calculation according to A. M. Zemskova formula [6]: DUC $\left(d_{1}{ }^{2}+d_{2}{ }^{2}\right) /\left(M_{2}-M_{1}\right)$, where $d_{1}$ is the mean average deviation of a healthy person's parameters; $d_{2}$ is the mean square deviation of children with NDTB parameters; $M_{1}$ and $M_{2}$ are the average means, respectively. The coefficient which had a value of 1 , was considered highly informative, in the range from 1.1 to 10 was medium-informative, exceeding 10 was low informative.

The results of the study were processed by modern methods of analysis on a personal computer using statistical software package Statistica ${ }^{\circledR}$ for Windows 6.0 (StatSoft Inc., AXXR712 D833214FAN5). The distribution of quantitative characteristics normality was analyzed using the Shapiro-Wild's test. The descriptive statistics for quantitative variables distributed under the normal distribution law included the mean $(\mathrm{M})$, standard deviation $(\sigma)$. The confidence interval for the mean with confidence probability of 0.95 was built. The reliability of compared values differences was determined by the Student's t-criterion. All tests were bi-directional. The difference for $\mathrm{P}<0.05$ was considered statistically significant. Correlation analysis was performed using the Pearson correlation coefficient ( $r$ ).

\section{Results and discussion}

On hospital admission 5 (17.8\%) children with NDTB were diagnosed with extrapulmonary forms of tuberculosis, 3 $(10.7 \%)$ of them had tuberculosis of the intracranial lymph glands and $2(7.1 \%)$ had specific pleurisy. 23 patients $(82.2 \%)$ were diagnosed with pulmonary forms: $5(17.8 \%)$ 
Table 5. Correlation between Ig content levels and protein fractions parameters among children with NDTB

\begin{tabular}{|c|c|c|c|c|c|c|c|c|}
\hline \multirow{3}{*}{$\begin{array}{l}\text { Indicators } \\
\text { of protein fractions }\end{array}$} & \multicolumn{8}{|c|}{ Ig indicators } \\
\hline & \multicolumn{2}{|l|}{$\lg E$} & \multicolumn{2}{|l|}{$\lg A$} & \multicolumn{2}{|l|}{$\lg M$} & \multicolumn{2}{|l|}{$\lg G$} \\
\hline & $r$ & $p$ & $r$ & $p$ & $r$ & $p$ & $r$ & $p$ \\
\hline Albumens & -0.386 & $<0.05$ & -0.486 & $<0.01$ & -0.355 & $>0.05$ & -0.619 & $<0.001$ \\
\hline$\alpha_{1}$-globulins & 0.08 & $>0.05$ & 0.336 & $>0.05$ & -0.167 & $>0.05$ & 0.318 & $>0.05$ \\
\hline$\alpha_{2}$-globulins & -0.107 & $>0.05$ & 0.246 & $>0.05$ & 0.08 & $>0.05$ & 0.098 & $>0.05$ \\
\hline$\beta$-globulins & 0.200 & $>0.05$ & 0.524 & $<0.01$ & 0.284 & $>0.05$ & 0.481 & $<0.01$ \\
\hline Y-globulins & 0.384 & $<0.05$ & 0.233 & $>0.05$ & 0.399 & $<0.05$ & 0.393 & $<0.05$ \\
\hline
\end{tabular}

had pleurisy, $5(17.8 \%)$ had primary tuberculosis complex, $11(39.5 \%)$ had infiltrative form and $2(7.1 \%)$ - disseminated. Bacterial secretion and destructive process in the lungs were registered in 7 children ( $25 \%$ ). Local forms of tuberculosis without a destructive process in the lungs were diagnosed in children with an average age of $5.4 \pm 1.5$, and disseminated tuberculosis including a destructive process presence were diagnosed among two times older children with an average age of $12.5 \pm 1.1$.

During blood serum Ig E, A, M, G total levels investigation in children with NDTB at the beginning of the IF AMBT (Table 1), reliable changes have been found only in the $\lg E$ and $A$. Thus, the level of $\lg E$ was within normal range in 13 patients (46.5\%), and it was elevated in 15 $(53.5 \%)$. The average lgE level exceeded the age norm by 2.1 times $(P<0.05)$. IgA levels were high only in $2(7.1 \%)$ and the level of all the other 26 children $(92.9 \%)$ indicators were within the normal range. The mean IgAlevel exceeded the age-matched norm in 1.2 times $(P<0.05)$. IgM levels in all $100 \%$ cases were within the age range. IgG level was decreased in 1 patient $(7.1 \%)$, and the average level of its content did not exceed the norm. Furthermore the direct correlation of $\lg E$ and $\lg A$ levels $(r=0.309 ; P<0.05)$, IgA and $\lg M(r=0.341 ; P<0.05)$ have been found.

When analyzing the changed levels of Ig depending on tuberculosis prevalence, (Table 2), the following features have been established. At normal average values the level of IgG content reliably depended on tuberculosis severity, namely its prevalence and destructive process presence. Thus, its level growth in 1.2 times $(P<0.05)$ was determined when disseminated process in comparison with the local without destructions. The lgE level increase in 1.2 times was also diagnosed in children with a disseminated process. The levels of IgA and lgM did not depend on the prevalence and destructive process presence.

The direct correlation of $\lg E$ and $\lg A$ levels $(r=0.365$; $P<0.025)$, $\lg A$ and $\lg M(r=0.382 ; P<0.025)$, $\lg M$ and $\lg G$ $(r=0.448 ; P<0.01)$ have been detected in the disseminated process. Direct correlation bonds have been detected only between IgA and IgM levels ( $r=0.448 ; P<0.01)$.

DUCs were calculated for all Ig parameters in the local process without destructions. It has been found that the DUCs for $\lg A, M$, and $G$ values were up to 1.0 $(0.05 ;-0.08$ and 0.94 respectively), indicating their high informativeness for diagnosis. IgE informational content was average, since its CG was 14.9. When studying the correlation of Ig levels with the dimensions of BCG post-vaccination signs among vaccinated children with NDTB a direct correlation between the decrease in the sign size and the $\lg E$ level increase $(r=0.670 ; P<0.001)$ has been established.
So far as the $y$-globulin fraction contains immunoglobulins $\lg G, \lg A, \lg M, \lg E$, the analysis of protein fraction indicators (Table 3 ) has been performed. It has been established that children with VDTB at the beginning of IF AMBT had an increase in the albumin level in 1.5 times in comparison with healthy children $(P<0.05)$. Furthermore, a high level of albumin was diagnosed in 26 children (92.8\%) of the main group. In contrast, an increase in the proteins globulin fraction levels was determined by increasing the $\beta$ - and $\gamma$-globulins levels in 1.5 and 1.3 times $(P<0.05)$ respectively, which was recorded in 19 patients $(67.8 \%)$. The levels of $\alpha_{1}$ - and $\alpha_{2}$-globulins were within the age norm, indicating specific inflammatory process low activity in children at the beginning of treatment. The level of $\alpha_{2}$-globulins has been determined in 14 children (50\%).

Analysis of protein fractions altered levels depending on the prevalence of tuberculosis (Table 4) has showed the following results. Children with a common specific process had an increase in dysproteinemia, which was manifested by a decrease in albumin levels by $9 \%$ $(P<0.05)$ and an increase in the levels of $\beta$ - and $y$-globulins in 1.3 times $(P<0.05)$. In this context, an increase in the inflammatory specific process activity was determined, indicating an increase in the level of $\alpha_{1}$-globulin in 1.3 times $(P<0.05)$.

DUC was also calculated for all protein fractions parameters. It has been established that DUC for albumin indicators, $\beta$ - and $y$-globulin values were up to $1.0(0.16$, 0.13 and 0.37 respectively), indicating their high informativeness for diagnosis. The informativeness of the $\alpha_{1}$ - and $\alpha_{2}$-globulin indices was average, since their DUC were 1.11 and 4.49 respectively.

The investigation of correlation between levels of $\lg$ content and protein fractions parameters (Table 5) made it possible to establish that children with NDTB at the beginning of IF AMBT had a decrease in albumin levels which was associated with an increase in $\lg E, A$, and $G$ levels. The growth in $\beta$-globulin levels was associated with an increase in levels of $\lg A$ and $G$, and $\gamma$-globulins $\lg E, M$ and $G$.

\section{Conclusions}

1. Children with NDTB, at the beginning of the IF AMBT had a significant increase in $\lg \mathrm{E}$ and $\mathrm{A}$ levels in 2.1 and 1.2 times, respectively. With an increase in the specific process prevalence and destruction appearance there was a significant increase in the lgG level in 1.2 times. Direct correlation of $\lg E$ and $\lg A, \lg A$ and $\lg M, \lg M$ and $\lg G$ in the disseminated process, and IgA, IgM levels in the local process has been established. 
2. A reliable correlation between the decrease in the BCG post-vaccination sign size and the increase in $\lg \mathrm{E}$ content has been found which can be a prognostic factor in the evaluation of post-vaccination immunity.

3. The activation of immune system cellular component is determined among the children as evidenced by a significant increase in albumins level in 1.5 times against the background of specific inflammatory process low activity (levels of $\alpha_{1}$ - and $\alpha_{2}$-globulins were within the age range). There is a significant increase in dysproteinemia (a decrease in albumin levels by $9 \%$ and an increase in $\beta$ - and $\gamma$-globulins levels in 1.3 times) and specific inflammatory process activity (an increase in $\alpha_{1}$-globulin levels in 1.3 times) with the increase in the specific process prevalence and destruction appearance.

4. It has been established that the decrease in the albumin level is associated with the growth in $\lg E, A$ and $G$ levels; the growth in $\beta$-globulin levels is associated with the growth in IgA and $G$ levels, and with $\lg E, M$ and $G$ - in y-globulins.

5 . It has been found that $\lg A, M$ and $G$ and the protein fractions parameters - albumins, $\beta$ - and $y$-globulins are significant and highly informative for the immune changes diagnosis among children with NDTB.

Prospects for further researches. The revealed changes are the basis for the development of rationally directed immunocorrective therapy among children with NDTB, and it will contribute to improvement of treatment effectiveness.

\section{References}

[1] Belogortseva, O. I. (2014). Epidemiolohichna sytuatsiia shchodo tuberkulozu u ditei v Ukraini ta shliakhy udoskonalennia nadannia protytuberkuloznoi dopomohy ditiam [The epidemiological situation of tuberculosis in children in Ukraine and ways to improve TB care to children]. Sovremennaya pediatriya, 5, 22-26. [in Ukrainian].

[2] Bilogortseva, O. I., Pobedonna, G. P., Rekalova, O. M., Dotsenko, Ya. I., Koposova, I. V., \& Firsova, A. P. (2015). Osoblyvosti stanu imunitetu u ditei, khvorykh na vpershe diahnostovanyi tuberkuloz [Peculiarities of immune status in children with newly diagnosed tuberculosis]. Ukrainskyi pulmonolohichnyi zhurnal, 3, 20-24. [in Ukrainian].

[3] Ckvitinidze, S., Ahvlediani, L., Khukhunaishvilli, R., Koridze, M., \& Nagervadze, M. (2012). Uroven' immunoglobulinov IgM, IgG i IgA pri tuberkuleze legkih [The level of immunoglobulins IgM, IgG and IgA for pulmonary tuberculosis]. Allergologiya i immunologiya, 13(3), 249-251. [in Russian].

[4] Vivchar, I. S., \& Zaletskiy, N. P. (2013). Korrelyacionnye svyazi pokazatelej immunnogo i citokinovogo statusa u detej i podrostkov, bol'nykh tuberkulezom legkikh [Correlation of indicators immune and cytokine status in children and adolescents with pulmonary tuberculosis]. Sovremennye problemy nauki i obrazovanija, 6. Retrieved from: https:// www.science-education.ru/ru/article/view?id=11059 (data obrashhenija: 03.09.2017). [in Russian]

[5] Moroz, I. A. (2001). Opredelenie belkov syvorotki krovi u bol'nykh tuberkulezom. [Determination of serum proteins in patients with tuberculosis]. Laboratornaya diagnostika tuberkuleza, 150-169. [in Russian].

[6] Kozhakhmetova, D. K., Maukayeva, S. B., Nuralinova, G. I., Tusupova, K. N., Kuanysheva, S. G., \& Kudaybergenova, N. K. (2014). Ocenka diagnosticheskoj znachimosti immunologicheskikh testov pri khronicheskom subkompensirovannom brucelleze [Evaluation of significance of immunological tests at chronic subcompensative brucellosis] Uspekhi sovremennogo estestvoznaniya, 6, 43-44. [in Russian].

\section{Information about authors:}

Raznatovska 0. M., MD, PhD, DSc, Associate Professor, Professor, Department of Phthisiology and Pulmonology, Zaporizhzhia State Medical University, Ukraine.

Mironchuk Yu. V., MD, Teacher Trainee, Department of Phthisiology and Pulmonology, Zaporizhzhia State Medical University, Ukraine.
Lytvynenko O. S., Assistant, Department of Pharmacology and Medical Formulation; Category I Specialist, Educational Medical-Laboratory Centre, Zaporizhzhia State Medical University, Ukraine.

\section{Відомості про авторів:}

Разнатовська О. М., А-р меА. наук, Аоцент, професор каф. фтизіатрії і пульмонології, Запорізький державний медичний університет, Україна.

Мирончук Ю. В., викладач-стажист каф. фтизіатрії і пульмонології, Запорізький державний медичний університет, Україна.

^итвиненко О. С., асистент каф. фармакології і медичної рецептури, спеціаліст I категорії Навчального медикомабораторного центру, Запорізький державний медичний університет, Україна.

\section{Сведения об авторах:}

Разнатовская Е. Н., А-р меА. наук, Аоцент, профессор каф. фтизиатрии и пульмонологии, Запорожский государственный медицинский университет, Украина. Мирончук Ю. В., преподаватель-стажер каф. фтизиатрии и пульмонологии, Запорожский государственный меАицинский университет, Украина.

Аитвиненко Е. С., ассистент каф. фармакологии и медицинской рецептуры, специалист I категории Учебного медиколабораторного центра, Запорожский государственный медицинский университет, Украина.

Conflicts of Interest: authors have no conflict of interest to declare. Конфмікт інтересів: віАсутній.

Надійшла Ао редакції / Received: 11.09.2017 Після Аоопрацювання / Revised: 26.09.2017 Прийнято Ао Аруку / Accepted: 01.11.2017 